\title{
High dose gammaglobulin treatment for atopic dermatitis
}

\author{
H Kimata
}

\begin{abstract}
Patients with both severe atopic dermatitis and Kawasaki disease or idiopathic thrombocytopenic purpura were treated with high dose intravenous gammaglobulin. There was a marked improvement in the dermatitis.

(Arch Dis Child 1994; 70: 335-336)
\end{abstract}

High dose intravenous gammaglobulin (IVGG) treatment is effective for Kawasaki disease and idiopathic thrombocytopenic purpura (ITP). ${ }^{12}$ Atopic dermatitis is an inflammatory skin disease of wide prevalence characterised by chronic pruritus and increased serum IgE. Although interferon gamma can be effective in treating severe atopic dermatitis it causes headache, fever, and myalgia. ${ }^{3}$ We treated two patients with atopic dermatitis and Kawasaki disease and two patients with atopic dermatitis and ITP with IVGG and found a marked improvement in the dermatitis.

\section{Subjects and methods}

All the patients studied had clinical features of severe atopic dermatitis by Hanfin's grading and by our skin scoring system. ${ }^{45}$ Patients 1,2 , and 3 were allergic to house dust mite, egg, and milk and patient 4 was allergic to house dust mite, egg, and cedar pollen by scratch test and radioallergosorbent test (RAST) score. Moreover, all of the patients' parents had allergy, including allergic rhinitis, atopic dermatitis, or allergic conjunctivitis. The severity of atopic dermatitis was assessed by our scoring system which assesses severity of inflammation, lichenification, and cracking on four areas of the body: face, trunk, arms, and legs. The maximum possible score is 24 . Scores for itch were assessed as no itching (score 0 ); mild, only itching at times (score 1); moderate, frequent itching, annoying (score 2); severe, constant itching, distressing (score 3). Scores for sleep were assessed as sound sleep, no disturbance (score 0 ); some difficulty in going to sleep, no disturbance during night

Table 1 Patient characteristics

\begin{tabular}{llllll}
\hline $\begin{array}{l}\text { Patient } \\
\text { No }\end{array}$ & $\begin{array}{l}\text { Age } \\
\text { (years) }\end{array}$ & Sex & Disease & $\begin{array}{l}\text { Dosage of IVGG } \\
\text { (g/day for 5 days) }\end{array}$ & $\begin{array}{l}\text { Duration of } \\
\text { atopic dermatitis }\end{array}$ \\
\hline 1 & $2 \cdot 5$ & F & Kawasaki disease & 4 & 9 months \\
2 & 3.5 & M & Kawasaki disease & 5 & $2 \cdot 5$ years \\
3 & $2 \cdot 0$ & F & ITP & 4 & 1.5 years \\
4 & 6.0 & M & ITP & 6 & 2.5 years \\
\hline
\end{tabular}

(score 1); difficulty in going to sleep, disturbed once or twice during night (score 2); great difficulty going to sleep, disturbed many times during night (score 3 ). 5

For each of the patients, treatment with steroid ointments, antihistamines, and antiallergic medication had proved unhelpful. Patients 1 and 2 had typical features of Kawasaki disease, including fever, polymorphous exanthema of the trunk, conjunctival conjestion, and strawberry tongue. Patients 3 and 4 had extensive purpura. At admission each was given IVGG (S-sulphonated intact gammaglobulin; Venilon, Teijin, Japan) at a dose of $400 \mathrm{mg} / \mathrm{kg}$ daily for five days from day 1 of treatment (table 1). No other drugs, including oral steroids, oral antihistamines, antiallergic medication or steroid ointments, were given to the patients. The effect of IVGG on atopic dermatitis was determined by comparison with day 1 (baseline), and after IVGG treatment on day 4, 7, and 14. All results are reported as means. Statistical analysis was performed with two tailed $t$ test.

\section{Results and discussion} CLINICAL COURSE

In patients 1 and 2, each of whom had Kawasaki disease, fever subsided on day 4 and 7 of the IVGG treatment respectively. On day 4 , in patient 1 , but not in patient 2 , atopic dermatitis was significantly $(p<0.01)$ improved as demonstrated by a decrease in scores for skin, itch, and sleep and there were also significant decreases $(p<0.01)$ in serum IgE, blood eosinophil count, and in vitro spontaneous IgE production $^{6}$ (table 2 ). In patients 3 and 4 , each of whom had ITP, the platelet count increased from 21 and $41 \times 10^{9} / 1$ at baseline to 51 and $81 \times 10^{9} / 1$ on day 4 , and 312 and $167 \times 10^{9} / 1$ on day 7 of IVGG treatment respectively. On day 4 , in patient 4 , but not in patient 3 , atopic dermatitis was significantly improved $(p<0.01)$ and there were significant decreases $(p<0.01)$ in serum IgE, blood eosinophil count, and in vitro spontaneous IgE production (table 2 ). In all of the patients, atopic dermatitis was significantly improved $(p<0(01)$ on day 7 and there were significant decreases $(p<0.01)$ in serum IgE, blood eosinophil count, and in vitro spontaneous IgE production. ${ }^{6}$ Each of these decreased further on day $14(p<0.01)$ compared with values on day 7 , at which time there was nearly complete resolution of atopic dermatitis. No adverse reactions to IVGG treatment were noted in any of the patients. 
Table 2 Effect of IVGG on atopic dermatitis

\begin{tabular}{|c|c|c|c|c|c|c|}
\hline & \multicolumn{3}{|l|}{ Score } & \multirow{2}{*}{$\begin{array}{l}\text { Serum IgE } \\
(\mu g / l)\end{array}$} & \multirow{2}{*}{$\begin{array}{l}\text { Eosinophil } \\
\text { count } \\
\left(\times 10^{9} /\right)\end{array}$} & \multirow{2}{*}{$\begin{array}{l}\text { IgE } \\
\text { production * } \\
(\mu g / l)\end{array}$} \\
\hline & Skin & Itch & Sleep & & & \\
\hline $\begin{array}{l}\text { Patient } 1 \text { (Kawasa } \\
\text { Baseline } \\
\text { Day } 4 \\
\text { Day } 7 \\
\text { Day } 14 \\
\text { After } 6 \text { months }\end{array}$ & $\begin{array}{c}\text { sease) } \\
18 \\
13 \\
8 \\
1\end{array}$ & $\begin{array}{l}3 \\
2 \\
1 \\
0\end{array}$ & $\begin{array}{l}3 \\
2 \\
1 \\
0\end{array}$ & $\begin{array}{r}23.4 \\
18.8 \\
13.9 \\
1.0 \\
0.8\end{array}$ & $\begin{array}{l}1.23 \\
0.98 \\
0.56 \\
0.32\end{array}$ & $\begin{array}{l}7 \cdot 9 \\
5 \cdot 2 \\
2 \cdot 1 \\
0 \cdot 5\end{array}$ \\
\hline $\begin{array}{l}\text { Patient } 2 \text { (Kawasa } \\
\text { Baseline } \\
\text { Day } 4 \\
\text { Day } 7 \\
\text { Day } 14 \\
\text { After } 6 \text { months }\end{array}$ & $\begin{array}{c}\text { sease) } \\
19 \\
17 \\
11 \\
2\end{array}$ & $\begin{array}{l}3 \\
3 \\
2 \\
1\end{array}$ & $\begin{array}{l}3 \\
3 \\
2 \\
0\end{array}$ & $\begin{array}{r}30 \cdot 6 \\
24 \cdot 9 \\
16 \cdot 1 \\
1 \cdot 4 \\
1 \cdot 1\end{array}$ & $\begin{array}{l}1.63 \\
1.60 \\
1.02 \\
0.45\end{array}$ & $\begin{array}{r}10.4 \\
9.4 \\
2.2 \\
<0.3\end{array}$ \\
\hline $\begin{array}{l}\text { Patient } 3(I T P) \\
\text { Baseline } \\
\text { Day } 4 \\
\text { Day } 7 \\
\text { Day } 14 \\
\text { After } 6 \text { months }\end{array}$ & $\begin{array}{r}19 \\
18 \\
10 \\
2\end{array}$ & $\begin{array}{l}3 \\
3 \\
2 \\
1\end{array}$ & $\begin{array}{l}3 \\
3 \\
2 \\
0\end{array}$ & $\begin{array}{r}22 \cdot 4 \\
21 \cdot 4 \\
17 \cdot 8 \\
2 \cdot 2 \\
2 \cdot 1\end{array}$ & $\begin{array}{l}2 \cdot 13 \\
2 \cdot 10 \\
1.58 \\
0.57\end{array}$ & $\begin{array}{r}11.3 \\
10.4 \\
3.2 \\
0.6\end{array}$ \\
\hline $\begin{array}{l}\text { Patient } 4(I T P) \\
\text { Baseline } \\
\text { Day } 4 \\
\text { Day } 7 \\
\text { Day } 14 \\
\text { After } 6 \text { months }\end{array}$ & $\begin{array}{r}20 \\
15 \\
11 \\
2\end{array}$ & $\begin{array}{l}3 \\
2 \\
2 \\
1\end{array}$ & $\begin{array}{l}3 \\
2 \\
2 \\
0\end{array}$ & $\begin{array}{r}24 \cdot 7 \\
19 \cdot 8 \\
17 \cdot 8 \\
2 \cdot 1 \\
2 \cdot 2\end{array}$ & $\begin{array}{l}2 \cdot 10 \\
1.68 \\
1.49 \\
0.73\end{array}$ & $\begin{array}{r}12 \cdot 9 \\
9 \cdot 2 \\
7 \cdot 4 \\
0 \cdot 8\end{array}$ \\
\hline Controls† & 0 & 0 & 0 & $0.05-0.62$ & $0-0.4$ & $<0.3$ \\
\hline
\end{tabular}

*Spontaneous IgE production was determined. ${ }^{6}$

†Values are based on age matched healthy children.

Six months after treatment, the two patients with Kawasaki disease were free of coronary aneurysm and the atopic dermatitis and had required no further treatment. One year after treatment, the two patients with ITP were free of both thrombocytopenia and atopic dermatitis and also had required no further treatment. Their serum IgE concentrations were moderately raised at the endof this period. The mechanisms by which high dose IVGG improves atopic dermatitis remains to be elucidated. It is particularly surprising that the affect lasted for more than six months. Our preliminary in vitro experiments show, however, that IgG, but not $\operatorname{IgM}$ or $\operatorname{Ig} A$, decreases $\operatorname{IgE}$ and tumour necrosis factor- $\alpha$ production (manuscript in preparation). Our findings show that high dose IVGG can be considered as a safe and effective treatment for severe atopic dermatitis in children.

1 Furusho $\mathrm{K}$, Nakano $\mathrm{H}$, Shinomiya $\mathrm{K}$ et al High-dose intravenous gamma globulin for Kawasaki disease. Lancet 1984; ii: 1055-7.

2 Impach P, Barandun S, Wagner HP, et al. High-dose intravenous gamma-globulin for idiopathic thrombocytopenic purpura in childhood. Lancet 1981; i: 1228-31.

3 Bogunewicz M, Jaffe HS, Izu A, et al. Recombinant gamma interferon in treatment of patients with atopic dermatitis and elevated IgE levels. Am $\mathcal{F}$ Med 1990; 88: 365-70.

4 Hanfin JM, Rajika G. Diagnostic features of atopic dermatitis. Acta Derm Venereol 1980; 92 (suppl): 44-7.

5 Kimata H, Igarashi M. Topical cromolyn (disodium cromoglycate) solution in the treatment of young children with atopic dermatitis. Clin Exp Allergy 1990; 20: 281-3.

6 Kimata H, Yoshida A, Ishioka C, Lindley I, Mikawa H. Interleukin 8 selectively inhibits IgE production induced by interleukin 4 in human B cells. $\mathcal{F} \operatorname{Exp} M e d$ 1992; 176: 1227 31 . 